\title{
The Impact of ASEAN-Korea Free Trade Agreements on Indonesian Export of Manufacturing Goods
}

\author{
Bernadheta Mia Tri Mareta
}

\begin{abstract}
Along with an attempt to promote the export performance of manufacturing goods, the number of investigation about the potential benefit or harm of free trade agreements is still weak in Indonesia. This paper highlights the effect of ASEAN-Korea Free Trade Agreement (AKFTA) on Indonesian export of manufacturing products since AKFTA as one of the significant initiatives in Southeast Asia is expected to boost Indonesian export. By using augmented gravity models with panel data, this paper investigates the presence of trade creation and trade diversion effects on Indonesian export with 20 trading partners, covering a 26-year period from 1990-2015. Fixed effects with least square dummy variable (LSDV) models are applied to tackle the endogeneity problems of FTA by controlling the unobserved heterogeneity. The results showed that trade diversion outweighs trade creation effects in almost all categories, confirming a decrease in export from member to non-member countries.
\end{abstract}

Keywords: AKFTA, trade creation, trade diversion, gravity model

\begin{abstract}
Abstrak. Di Indonesia, ketertarikan bergabung dalam berbagai skema perdagangan bebas kurang diimbangi dengan analisis yang mendalam mengenai dampaknya terhadap kinerja ekspor termasuk pada produk manufaktur yang mempunyai peranan penting dalam ekonomi negara. Penelitian ini bertujuan untuk menganalisa efek trade creation dan trade diversion dari implementasi ASEAN-Korea Free Trade Agreement (AKFTA), sebagai salah satu skema perdagangan yang cukup signifikan di ASEAN, pada export dari lima (5) kategori produk manufaktur di Indonesia dengan 20 negara mitra dagang yang termasuk anggota dan nonanggota AKFTA periode 1990-2015. Metode estimasi menggunakan model gravity yang dimodifikasi dengan menambahkan variabel dummy FTA sebagai proxi dari dampak implementasi AKFTA dengan variasi model fixed effects least square dummy variables untuk mengatasi masalah endogeneity. Hasil penelitian menunjukkan adanya efek trade diversion yang melebihi trade creation, mengindikasikan bahwa terjadi penurunan export dari negara anggota AKFTA.
\end{abstract}

Kata kunci: $A K F T A$, trade creation, trade diversion, model graviti

\section{How to Cite:}

Mareta, B. M. T. (2018). The Impact of ASEAN-Korea Free Trade Agreements on Indonesian Export of Manufacturing Goods. Etikonomi: Jurnal Ekonomi. Vol. 17 (2): 161 - 184. doi: http//dx.doi.org/10.15408/etk.v17i2.7342. 


\section{Introduction}

Recently, the Indonesian government has aimed to boost the export performance of manufacturing goods since this sector plays a vital role in Indonesia. In 2015, the performance of manufacturing industry was about $20.41 \%$ of GDP with the annual growth being about $4.33 \%$. However, with the rising interest to join Free Trade Agreement (FTA) including ASEAN-Korea Free Trade Agreement (AKFTA), the number of proper investigation about the potential benefit and/or harm of the agreement on the export of manufacturing products in Indonesia are still weak. Magee (2008) states that estimating FTA effects are essential since FTA could be either beneficial or harmful depending on the countries involved. According to Heo and Kien (2010), the effects of FTA on trade flows between member and non-member countries should be evaluated only on a case-by-case basis. Since Indonesia is a member of ASEAN, the formation of AKFTA may bring some effects on the economy. Therefore, this paper aims to study the impact of AKFTA implementation specifically on the export of Indonesian manufacturing goods.

AKFTA is one of the significant initiatives in Southeast Asia (Park et al., 2008). This agreement established in 2006 and its principles include tariff reductions and elimination of all tariff lines. In 2014, Korea became the second largest partner with whom ASEAN has formed FTA, while ASEAN was the second largest partner of Korea. According to Ha et al., (2016), Korea's total trade volume with ASEAN in 2014 amounted to 138 billion USD, making ASEAN the second-largest trading partner of Korea.

Many studies applied gravity model to investigate the impact of FTA implementation. The gravity model is a prominent technique of ex-post approaches which utilize data before and after FTA formation focusing on trade share of members and non-members (Macphee and Sattayanuwat, 2014). Gravity analyses have empirically attained success in explaining various types of intra and extra-regional flows including trade in goods (Cheng and Wall, 2005).

Since firstly developed, the gravity model has been widely used and has continually evolved. Some researchers add an FTA dummy variable to capture its effect on bilateral trade. This method was initially introduced by Aitken, followed by Soloaga and Winters (2001) and Elliot and Ikemoto (2004). However, the results were different. Soloaga and Winters (2001) concluded that the intra-regional trade effect in ASEAN was adverse. Elliot and Ikemoto (2004) found that the intra-regional trade effect in ASEAN was positive. The difference in methodology led to different results.

Afterward, some empirical studies utilize more than one FTA dummy variables to investigate the impact on member and non-member countries. Kien (2009) applied the second dummy to capture the presence of trade creation and trade diversion effects on members and non-members. Later on, the model has developed by using three dummy FTA variables for trade creation, export trade diversion, and import trade diversion. Several studies using such a model are Jugurnath et al., (2007), Macphee and Sattayanuwat (2014), Yang and Martinez-Zarzoso (2014), and Kahouli and Maktouf (2015).

The conceptual framework of trade creation and trade diversion firstly initiated by Viner (1950). Trade creation replaces higher priced domestic products with cheaper ones 
from members due to tariff reduction, and trade diversion occurs when imports from a member replace cheaper price imports from non-members (Zidi and Dhifallah, 2013). According to Viner (1950), FTA would generate benefit if the magnitude of trade creation is more significant than trade diversion; while it would be detrimental if the magnitude of trade creation is smaller than trade diversion. FTA promotes prosperity when trade creation outweighs trade diversion effects.

The other primary issue on this topic is the level of data analysis. Some analyses related to trade creation and trade diversion effects applied aggregated trade data. According to French (2011), using disaggregated data does not only allow identifying effects on single product groups, but it can be used as a basis to calculate aggregated trade costs more accurately. Thus, the analysis is likely more appropriate if applying disaggregated data as done by Yang and Martinez-Zarzoso (2014), Jayasinghe and Sarker (2008), and Okabe and Urata (2014).

This study attempts to investigate the impact of AKFTA establishment on the Indonesian export of manufacturing goods by taking into account the two issues mentioned above as the main contribution. By utilizing panel data with fixed effects approaches, this study tries to deal with the unobserved heterogeneity problem. To the best of authors' knowledge, this is the first work to attain ex-post unbiased estimates of AKFTA implementation on Indonesian manufacturing goods considering the endogeneity bias of this trade policy. Moreover, this study estimates the model using both aggregated data for total export of manufacturing goods and disaggregated data for five categories of manufacturing products: primary products, natural-resource intensive products, unskilledlabor intensive products, technology-intensive products and human-capital intensive products. This paper organized as follows. First, the overview of Indonesian manufacturing products and AKFTA in general. This overview along with literature review on the use of gravity model to investigate the impact of FTA implementation. Second, the methodology of the study and data for estimating the result. Finally, the results are discussed, followed by the conclusion and policy implications.

\section{Method}

This study utilizes panel data of bilateral trade flows between Indonesia and 20 tradepartner countries covering a 26-year period dating from 1992 to 2015 at both aggregated and disaggregated level. All export values taken from the United Nations Commodity Trade (UN-COMTRADE) database, a very comprehensive statistics database on international trade in goods; World Integrated Trade Solution (WITS), an integrated trade database provided by World Bank that compiles trade database from various sources (e.g., WTO, ITC); and are based on the Standard International Trade Classification (SITC) under Revision 2 in nominal values. GDP data in nominal values, nominal exchange rate, consumer price index (CPI), and trade openness obtained from the World Bank Development Indicators and International Monetary Fund. This paper takes bilateral distance data between trade partners from the CEPII database. 
A standard gravity model contains at least two independents variables, Gross Domestic Product (GDP) as a proxy of economic size, and distance as a proxy for transportation cost. In this case, variable distance is modified into remoteness. This paper applies a natural $\log$ for export, GDP, remoteness, real exchange rate and trade openness to control variability of each variable. The transformed value is possible to interpret the slope coefficient $\beta i$ as the elasticity of dependent variable $(\mathrm{Y})$ with respect to independent variables $(\mathrm{X})$, that is, the percentage change in $\mathrm{X}$ will give percentage change in $\mathrm{Y}$. The baseline augmented gravity model is given by:

$$
\begin{aligned}
& \ln \left(X_{i j t}\right)=\beta_{0}+\beta_{1} \ln \left(G D P_{i t)}+\beta_{2} \ln \left(G D P_{j t}\right)+\beta_{3}\left(R E M_{-} E x_{i t}\right)+\beta_{4}\left(R E M_{-} I_{j, t}\right)+\right. \\
& \beta_{5}\left(R E R_{i j, t}\right)+\beta_{6}\left(O P_{i j, t}\right)+\beta_{7}\left(f t a 1_{i j, t}\right)+\beta_{8}\left(f t a 2_{i j, t}\right)+\varepsilon_{i j t}
\end{aligned}
$$

$X_{i j t}$

$G D P_{i t}$

$G D P_{j t}$

$R E M_{-} E x_{i, t}$

$R E M_{-} I m_{j, t}$

$O P_{i, t}$

$R E R_{i j, t}$

fta1 $_{i j, t}$

$f t a 2_{i j, t}$

represents export value regarding U.S. dollars from country $i$ to country $j$ at time $t$

represents a nominal gross domestic product in US dollars of country $i$ at time $t$ represents a nominal gross domestic product in US dollars of country $j$ at time $t$ denotes remoteness of country $i$ at time $t$ denotes remoteness of country $j$ at time $t$ denotes trade openness index of country $i$ denotes the real exchange rate between country $i$ and country $j$ in year $\mathrm{t}$ dummy variable equals to 1 after 2007 if country $i$ and $j$ in year $t$ is a member of AKFTA (Indonesia and trading partners); is 0 if otherwise dummy variable equals to 1 after 2007 if exporter country $i$ in year $t$ is a member of AKFTA (Indonesia) and importer country $j$ is a non-member of AKFTA (trading partners); is 0 if otherwise

Table 1. Coefficient interpretation of FTA dummy variables

\begin{tabular}{lll}
\hline & & Effects on Export \\
\hline & $\left(\beta_{8}>0\right)$ & $\left(\beta_{8}<0\right)$ \\
& Pure trade creation on export & Trade creation and import diversion $\left(\beta_{7}>\beta_{8}\right)$ \\
& & Or export diversion $\left(\beta_{7}<\beta_{8}\right)$ \\
$\left(\beta_{7}>0\right)$ & $\begin{array}{l}\text { Expansion of export from non- } \\
\text { members }\end{array}$ & Export diversion and export contraction \\
\hline
\end{tabular}

Source: Yang and Martinez-zarzoso (2014)

In gravity model, the use of FTA dummy variables can be problematic due to endogeneity. International trade studies emphasize that trade policy should be treated as an endogenous rather than an exogenous variable (Baier and Bergstrand, 2007; Magee, 2008). Urata and Okabe (2014) said that endogenous bias might come from omitted variables included in the error term such as policy-related conditions to form an FTA. Baier and Bergstrand (2007) employed country-pair effects to account for the endogenous FTA variables in gravity regressions. Egger and Nigai (2015), Agnosteva et al., (2014), Piermartini 
and Yotov (2016) showed that country-pair effects lead to a better measure of bilateral trade costs compared to the standard of gravity variables. Furthermore, the model includes time effects, using the idea of Yang and Martinez-zarzoso (2014) that those effects may control for macroeconomic conditions which vary among countries, such as the presence of a financial crisis in the particular country. The first specified model is:

$\ln \left(X_{i j t}\right)=\beta_{0}+\beta_{1} \ln \left(G D P_{i t)}+\beta_{2} \ln \left(G D P_{j t}\right)+\beta_{3}\left(R E M_{E x_{i t}}\right)+\beta_{4}\left(R E M_{I m_{j, t}}\right)+\right.$

$\beta_{5}\left(R E R_{i j, t}\right)+\beta_{6}\left(O P_{i j, t}\right)+\beta_{7}\left(f_{t a 1} 1_{i j, t}\right)+\beta_{8}\left(f t a 2_{i j, t}\right)+\mu_{i j}+\gamma_{t}+\varepsilon_{i j t}$

In this model, $\mu_{i j}$ represents country-pair effect, and $\gamma_{t}$ represents time effect.

Additionally, the second model followed Matyas (1997) who proposed the use of country-specific and time effects to account for the multilateral resistance (MR) terms since they are not observable to produce theoretically consistent results. MR terms refer to all trade barriers faced by each country with all trading partners which should be included in the model to attain accurate estimates (Adam and Cobham, 2007). The basic idea is that the effects may capture all the individual time-invariant of exporters and importers that omitted in the model. Following the idea, the second models specified as:

$$
\begin{aligned}
& \ln \left(X_{i j t}\right)=\beta_{0}+\beta_{1} \ln \left(G D P_{i t)}+\beta_{2} \ln \left(G D P_{j t}\right)+\beta_{3}\left(R E M_{E x_{i t}}\right)+\beta_{4}\left(R E M_{I m_{j, t}}\right)+\right. \\
& \beta_{5}\left(R E R_{i j, t}\right)+\beta_{6}\left(O P_{i j, t}\right)+\beta_{7}\left(f t a 1_{i j, t}\right)+\beta_{8}\left(f t a 2_{i j, t}\right)+\varphi_{i}+\omega_{j}+\gamma_{t}+\varepsilon_{i j t}
\end{aligned}
$$

$\varphi_{i}$ is an exporter-specific effect, $\omega_{j}$ is an importer-specific effect, and $\gamma_{t}$ is time effect.

Furthermore, this study applies the time-varying fixed effects motivated by the methods of Anderson and van Wincoop. More recently, Olivero and Yotov (2012) showed that individual time-varying fixed effects should account for the MR terms in the gravity model with panel data. According to Yang and Martinez-zarzoso (2014), the panel data specification allows controlling for both time-varying and time-invariant heterogeneity by introducing country-time effects while maintaining the country-pair fixed effects. Thus, the model specified as:

$\ln \left(X_{i j t}\right)=\beta_{0}+\beta_{1} \ln \left(G D P_{i t)}+\beta_{2} \ln \left(G D P_{j t}\right)+\beta_{3}\left(R E M_{E x_{i t}}\right)+\beta_{4}\left(R E M_{I m_{j, t}}\right)+\right.$

$\beta_{5}\left(R E R_{i j, t}\right)+\beta_{6}\left(O P_{i j, t}\right)+\beta_{7}\left(\right.$ fta1 $\left._{i j, t}\right)+\beta_{8}\left(\right.$ fta2 $\left._{i j, t}\right)+\mu_{i j}+\theta_{i t}+\delta_{j t}+\varepsilon_{i j t}$

Here, $\mu_{i j}$ denotes the set of country-pair fixed effects; $\theta_{i t}$ and $\delta_{j t}$ denotes exporter-year dummies and importer-year dummies, respectively, which control other unobservable country-specific factors that may influence bilateral trade (Piermartini \& Yotov, 2016).

\section{Result and Discussion}

\section{Empirical Results on Indonesian Total Export}

Panel data tend to suffer from heteroscedasticity. According to Zidi and Dhifallah (2013). In the presence of heteroscedasticity, the estimates of the trade effects will be biased and inconsistent in log-linear form with the OLS estimator, as shown by Silva and Tenreyro (2006). Similarly, errors should not correlate for each in panel data analysis (Zidi and Dhifallah, 2013). The data used in this paper suffers from this problem due to the result of tests for both heteroscedasticity and autocorrelation. This study uses robust standard error in 
regression to overcome the problem of heteroscedasticity and autocorrelation.

First, the basic Equation (1) is estimated using a pooled OLS estimation by excluding time and individual dummy variables from the model. OLS technique solely pools all the data together but does not allow the distinction between specific trading pairs (Yang and Martinez-zarzoso, 2014). The basic augmented gravity model then regressed by applying the combination of fixed effects since the Hausman test also suggests that fixed effects are more appropriate for the data on total exports. Kepaptsoglou et al., (2010) stated that the most pertinent research for developing gravity models had applied fixed effects approaches since the seminal work of Anderson and Van Wincoop on theoretical foundations of the gravity models to adequately account for the endogeneity bias. This paper conducts this technique as a benchmark for other specifications as shown in Table 2 Column (1).

Table 2. Effects of FTA on Indonesian total export

\begin{tabular}{|c|c|c|c|c|c|}
\hline VARIABLES & Pooled OLS & $\mathrm{FE}$ & $F E, i j, t$ & $F E, i, j, t$ & 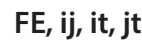 \\
\hline \multirow[t]{2}{*}{ InGDPnomi } & $0.781^{* * *}$ & $0.601^{* * *}$ & $0.978^{* * *}$ & $0.976^{* * *}$ & $0.603^{* * *}$ \\
\hline & $(0.012)$ & $(0.050)$ & $(0.019)$ & $(0.037)$ & $(0.018)$ \\
\hline \multirow[t]{2}{*}{ InGDPnomj } & $0.555^{* * *}$ & $0.664^{* * *}$ & $0.984^{* * *}$ & $0.777^{* * *}$ & $0.660^{* * *}$ \\
\hline & $(0.008)$ & $(0.053)$ & $(0.018)$ & $(0.047)$ & (0.019) \\
\hline \multirow[t]{2}{*}{ Tradeop } & $0.329^{* * *}$ & $0.140^{* * *}$ & $0.180^{* * *}$ & $0.180^{* * *}$ & $0.134^{* * *}$ \\
\hline & $(0.022)$ & $(0.028)$ & $(0.015)$ & $(0.036)$ & $(0.019)$ \\
\hline \multirow[t]{2}{*}{ remoteness_i } & $0.066^{* * *}$ & -0.001 & -0.002 & -0.003 & -0.001 \\
\hline & $(0.004)$ & $(0.008)$ & $(0.004)$ & $(0.008)$ & $(0.003)$ \\
\hline \multirow[t]{2}{*}{ remoteness_j } & $-0.179^{* *}$ & $267,3^{* * *}$ & $-1.541^{* * *}$ & & $-1.069^{* *}$ \\
\hline & $(0.069)$ & $(57,63)$ & $(0.283)$ & & $(0.437)$ \\
\hline \multirow[t]{2}{*}{ REER } & $-1.564^{* * *}$ & $-1.773^{* * *}$ & $-1.774^{* * *}$ & $-2.018^{* * * *}$ & $-1.768^{* * *}$ \\
\hline & $(0.061)$ & $(0.384)$ & $(0.133)$ & $(0.268)$ & $(0.146)$ \\
\hline \multirow[t]{2}{*}{$\mathrm{fta} 1$} & $0.706^{* * *}$ & 0.028 & -0.093 & $0.521^{* * *}$ & 0.027 \\
\hline & $(0.180)$ & $(0.124)$ & $(0.078)$ & $(0.058)$ & $(0.051)$ \\
\hline \multirow[t]{2}{*}{$\mathrm{fta} 2$} & $-0.605^{* * *}$ & $-0.272^{* * *}$ & $-0.291^{* * *}$ & $-0.567^{* * *}$ & $-0.273^{* * *}$ \\
\hline & $(0.120)$ & (0.099) & $(0.052)$ & $(0.082)$ & $(0.038)$ \\
\hline \multirow[t]{2}{*}{ Constant } & $9.854^{* * *}$ & $-3.978^{* * * *}$ & $17.70^{* * *}$ & 4.170 & $29.41^{* * * *}$ \\
\hline & $(1.370)$ & $(857,9)$ & (5.594) & $(4.670)$ & $(7.842)$ \\
\hline Observations & 10,709 & 10,709 & 10,709 & 10,709 & 10,709 \\
\hline R-squared & 0.526 & 0.680 & 0.945 & 0.735 & 0.939 \\
\hline \multicolumn{6}{|l|}{ Tipe of FE } \\
\hline countrypair & & & Yes & & Yes \\
\hline year & & & Yes & Yes & \\
\hline country specific & & & & Yes & \\
\hline country \& year & & & & & Yes \\
\hline
\end{tabular}

Note: Robust standard error in parentheses, ${ }^{* *} p<0.01,{ }^{* *} p<0.05,{ }^{*} p<0.1$ 
The results of Pooled OLS for total exports are significant for almost all of the explanatory variables with expected signs. The basic independent variables of the gravity model, GDP of the exporter, GDP of importer and trade openness, are found to have significant positive effects on exports as expected, while the sign of remoteness for both exporter and importer are negative, in line with the theory. However, the coefficient of the real exchange rate is negative, in contrast with the theory. In a model with a wide range of time, the real exchange rate is advisable to measure the competitiveness of exporting countries (Carrere, 2006; Trotignon, 2012). An increase in bilateral exchange rate, which is a depreciation of the domestic currency against the foreign currency, leads to an increase in bilateral trade regarding export (Narayan and Nguyen, 2016) and a decrease concerning import. Thus, it should have a positive sign on export and the negative sign on import (Jugurnath et al., 2007). A contra-intuitive sign reflects a weakness of trade elasticity (Trotignon, 2012).

One possible explanation is that a negative sign of this variable regarding exports may have a correlation with the competitiveness of domestic products compared to other countries which have a higher quality of the same products. As a result, the exports volume will decrease if domestic products have lower quality than products of other countries. The other explanation is that the economic condition of trading partners. If trading partners of Indonesia also experience the depreciation of their domestic currency, but with the higher magnitude, then, this condition likely reduces the Indonesian exports competitiveness, resulting in a reduction of Indonesian exports volume in the presence of depreciation.

The coefficients of fta 1 and fta 2 are also significant. Dummy fta 1 has a positive sign meaning that there is trade creation between Indonesia and member countries. A schedule for tariff reduction possibly makes the volume of exports go up when tariffs gradually become 0 . Dummy fta 2 has a significant negative sign, meaning that there is trade diversion of export destination from Indonesia to non-member countries. However, since there are problems with the existence of heteroscedasticity, autocorrelation, and heterogeneity based on the test results, the results are likely biased.

The results of the regression with the fixed effects model presented in Table 3.1 in Column (2). The results are mostly the same as with Pooled OLS results where all of the explanatory variables have significant coefficients, except for coefficient of dummy fta1 and remoteness exporters. Both coefficients become statistically insignificant. However, dummy $\mathrm{fta} 2$ remains significant and has negative signs, meaning that there was a trade diversion with non-member countries. In this case, Indonesia exports might divert to member countries of AKFTA replacing the previous trade flows from non-members.

Moreover, GDP nominal for exporter and importer have positive and significant results. If exporter GDP increases by $1 \%$, exports will increase as much as $0.60 \%$. Next, a $1 \%$ increase in partner's GDP will increase exports by $0.66 \%$. In this case, GDP positively impacts trade. Trade openness in this model has a positive sign and significant. If trade openness increases by $1 \%$, exports will grow by $0.14 \%$. 
Afterward, using the LSDV method of fixed effects, three models of Indonesian exports are estimated to achieve better results. As done before, Column (3) presents a fixed effect model with country-pair $\left(\mu_{i j}\right)$ and time dummies $\left(\gamma_{t}\right)$, Column (4) illustrates a model with time effects $\left(\gamma_{t}\right)$ and country-specific effects $\left(\varphi_{i}, \omega_{j}\right)$ and Column (5) shows a model with country-year $\left(\theta_{i t}, \delta_{j t}\right)$ and country-pair $\left(\mu_{i j}\right)$ effects. The results in Column (3), applying country-pair $\left(\mu_{i j}\right)$ and time dummies $\left(\gamma_{t}\right)$, are almost similar to those in Column (2). Almost all of the explanatory variables have significant coefficients at the $1 \%$ level with the expected signs, except for remoteness exporters and dummy variable ftal that become statistically insignificant and the real exchange rate that has an unexpected sign. In this case, GDP exporter, GDP importer and Trade openness have higher magnitudes than in Column (2). Trotignon (2010) stated that when a pair of economies is close to its trade partners, they would tend to trade more than two countries that are separated by the same distance but geographically near to other markets. Silva $\&$ Tenreyro (2006) stated that the most remote countries tend to trade more between each other because they do not have alternative trading partner.

Slightly different with the results of the fixed effects model considering time effects $\left(\gamma_{t}\right)$ and country-specific effect $\left(\varphi_{i}, \omega_{j}\right)$, the coefficients of fta1 in Column (4) are getting positive and statistically significant and are also higher in magnitude than in columns (2) and (3). The coefficient sign of $\mathrm{fta} 2$ remains negative. The positive coefficient of ftal indicates that the AKFTA has caused an intra-regional trade creation effect and increased the welfare of member countries. The dummy of fta2, which represents exports from AKFTA member countries to non-member countries, displays a significantly negative coefficient, which indicates reducing exports for the countries outside the trade bloc. As fta $1>0$, fta $2<0$ and $\mathrm{fta} 1<\mathrm{fta} 2$, a diversion effect regarding exports is identified in this model. For other variables, all coefficients are statistically significant at the $1 \%$ level. All coefficients had the expected signs except the real exchange rate. However, variable remoteness exporter is omitted.

Furthermore, as the dummy variables $\mathrm{fta} 1$ and $\mathrm{fta} 2$ vary in three dimensions $(i, j$, and $t$ ), Baier and Bergstrand (2007) suggested to include two types of dummy variables to control everything else, i.e., exporter-year and importer-year $\left(\theta_{i t}, \delta_{j t}\right)$ and country-pair $\left(\mu_{i j}\right)$ effects altogether. By doing so, the model controls for all determinants that vary in those dimensions with it and $j t$ (such as GDP, real exchange rate, and trade openness in country $i$ and $j$ ) and also the time-invariant effects between two countries. The results of a model with country-year $\left(\delta_{j t}\right)$ and country-pair $\left(\mu_{i j}\right)$ effects are presented in Column (5). All coefficients of variables are significant at $1 \%$ except for real exchange rate and fta 1 that are insignificant. All coefficients have the expected signs except for the real exchange rate variable. The coefficient of $\mathrm{fta} 2 \mathrm{has}$ negative and significant signs.

\section{Empirical Results on Export of Indonesian Manufacturing Goods}

Based on the previous results, the analysis for disaggregated data of Indonesian manufacturing export will regressed by using fixed effects model with country-pair and country-year effects only. The regression results presented in Table 3. In Column (1), 
coefficients of all of the variables are significant at the $1 \%$ level with expected signs, except for the real exchange rate, which has a converse sign, negative, and dummy fta2 that becomes insignificant. For the main variable GDP, if the GDP exporter increases by $1 \%$, total exports will increase as much as $0.61 \%$. After that, a $1 \%$ increase in the GDP importer will increase total exports by $0.64 \%$. In this case, GDP positively impacts trade. In the event of remoteness, both the remoteness exporter and importer have a negative sign. As a proxy for transportation cost, if there is a $1 \%$ increase in these variables, then the total exports of Indonesia will decrease by about $1.17 \%$ and $1.60 \%$, respectively. The volume of exports of Indonesian manufacturing goods will decline if the trade cost increases. In the case of trade openness, it has a statistically significant coefficient and a negative sign. If there is $1 \%$ increase in this variable, consequently, the total export volume will go up $0.13 \%$.

Moreover, the real exchange rate also has a negative sign, in contrast with the theory, even though the coefficient is significant. Devadason (2010) said that the real exchange rate could measure the competitiveness of the exporting country against its partner. The negative sign may correlate with the competitiveness of domestic products compared to other countries. It will reduce the number of export if the domestic products have lower quality than the products from other countries. If the real exchange rate of the Indonesian Rupiah to the currency of its partner increases by $1 \%$, exports to Indonesia will decline by $1.60 \%$.

Furthermore, the coefficient of fta1 is not significant, but the coefficient of fta2 remains statistically significant at the $1 \%$ level Dummy fta 1 has insignificant sign meaning that there is no evidence for trade creation effect between Indonesia and member countries for total export of manufacturing goods. The coefficient sign of fta2 is negative, which means that when the trade partner is a non-member of AKFTA, Indonesian exports to this particular country will be smaller than those who are a member of AKFTA. The coefficient value infers that if the trade partner is a non-member of AKFTA, Indonesian exports of manufacturing products will go down by $22 \%$, holding other factors constant. Thus, only the trade diversion effect occurs in this case.

In Column (2), coefficients of variable GDP are statistically significant at $1 \%$. However, the signs for remoteness importer and the real exchange rate are not as expected. If the GDP exporter increases by $1 \%$, total exports will increase as much as $0.26 \%$. Then, a $1 \%$ increase in the GDP importer will increase total exports by $1.03 \%$. In this case, GDP positively impacts exports of primary products. Variables remoteness exporter is significant at the $1 \%$ level, and the sign is negative, in line with the theory. As a proxy for transportation cost, Indonesian exports will increase by about 3.5\% when there is $1 \%$ increase in this variable. On the other hand, in contrast with the theory, the remoteness importer has a positive sign. If there is a $1 \%$ increase in these variables, then the exports of primary products will decrease about $33.9 \%$. The export volume of primary goods will decline if the trade cost increases. In this case, Indonesia is geographically close to many trade partners, so the exports tend to be higher. 
Moreover, in the case of trade openness, it has statistically significant coefficient and a positive sign. If there is a $1 \%$ increase in this variable, consequently, the primary product exports volume will go up $0.14 \%$. The real exchange rate also has a negative sign, in contrast with the theory, even though the coefficient is significant. Holding other factors constant, if the real exchange rate of the Indonesian Rupiah to the currency of the partner country increases by $1 \%$, Indonesian exports of primary products will decline by $0.67 \%$.

Table 3. Effects of FTA on The Export of Manufacturing Goods in Indonesia

\begin{tabular}{|c|c|c|c|c|c|c|}
\hline Variables & $\begin{array}{l}\text { Total Export of } \\
\text { manufacturing } \\
\text { products }\end{array}$ & $\begin{array}{l}\text { Primary } \\
\text { products }\end{array}$ & $\begin{array}{l}\text { Natural- } \\
\text { resource } \\
\text { intensive } \\
\text { products }\end{array}$ & $\begin{array}{l}\text { Unskilled- } \\
\text { labor } \\
\text { intensive } \\
\text { products }\end{array}$ & $\begin{array}{l}\text { Technology } \\
\text { intensive } \\
\text { products }\end{array}$ & $\begin{array}{l}\text { Human- } \\
\text { capital } \\
\text { intensive } \\
\text { products }\end{array}$ \\
\hline \multirow[t]{2}{*}{ InGDPnomi } & $0.608^{* * *}$ & $0.261^{* * *}$ & $0.505^{* * *}$ & $0.517^{* * *}$ & $1.009^{* * *}$ & $0.608^{* * *}$ \\
\hline & (0.019) & $(0.023)$ & $(0.026)$ & $(0.027)$ & $(0.023)$ & $(0.024)$ \\
\hline \multirow[t]{2}{*}{ InGDPnomj } & $0.645^{* * *}$ & $1.036^{* * *}$ & $0.679^{* * *}$ & $0.441^{* * *}$ & $0.431^{* * *}$ & $0.662^{* * *}$ \\
\hline & $(0.022)$ & $(0.023)$ & $(0.029)$ & $(0.0301)$ & $(0.026)$ & $(0.027)$ \\
\hline \multirow[t]{2}{*}{ Tradeop } & $0.128^{* * *}$ & $0.140^{* * *}$ & $0.160^{* * *}$ & $0.0592^{* *}$ & $0.244^{* * *}$ & $0.229 * * *$ \\
\hline & $(0.018)$ & $(0.021)$ & $(0.032)$ & $(0.023)$ & $(0.036)$ & $(0.028)$ \\
\hline \multirow[t]{2}{*}{ remoteness_i } & -0.00145 & $-0.0354^{* * *}$ & $0.0244^{* * *}$ & $-0.0165^{* * *}$ & $0.0134^{* * *}$ & $0.0188^{* * *}$ \\
\hline & $(0.003)$ & $(0.005)$ & $(0.005)$ & $(0.005)$ & $(0.004)$ & $(0.004)$ \\
\hline \multirow[t]{2}{*}{ remoteness_j } & $-1.168^{* * *}$ & $3.393^{* * *}$ & $1.898^{* * *}$ & $-7.974^{* * *}$ & $-2.534^{* * *}$ & $-3.894^{* * *}$ \\
\hline & $(0.447)$ & $(0.328)$ & $(0.645)$ & $(0.909)$ & $(0.721)$ & $(0.634)$ \\
\hline \multirow[t]{2}{*}{ REER } & $-1.604^{* * *}$ & $-0.673^{* * *}$ & $-2.153^{* * *}$ & $-1.993^{* * *}$ & $-1.517^{* * *}$ & $-2.529 * * *$ \\
\hline & $(0.143)$ & $(0.178)$ & $(0.240)$ & $(0.272)$ & $(0.211)$ & $(0.236)$ \\
\hline \multirow[t]{2}{*}{$\mathrm{fta} 1$} & 0.0106 & $0.467^{* * *}$ & 0.159 & $-0.229 * * *$ & $-0.291^{* * *}$ & $0.215^{* *}$ \\
\hline & $(0.054)$ & $(0.0629)$ & $(0.102)$ & $(0.074)$ & $(0.085)$ & $(0.092)$ \\
\hline \multirow[t]{2}{*}{$\mathrm{fta} 2$} & $-0.218^{* * *}$ & $0.288^{* * *}$ & $-0.898^{* * *}$ & $-0.556^{* * *}$ & $-0.114^{* *}$ & $-0.243^{* * *}$ \\
\hline & $(0.037)$ & $(0.051)$ & $(0.056)$ & $(0.050)$ & $(0.057)$ & $(0.049)$ \\
\hline \multirow[t]{2}{*}{ Constant } & $28.82^{* * *}$ & $-56.44^{* * *}$ & -11.31 & $142.3^{* * *}$ & $40.16^{* * *}$ & $79.42^{* * *}$ \\
\hline & (7.998) & $(7.083)$ & (11.89) & $(15.82)$ & $(12.51)$ & $(11.72)$ \\
\hline Observations & 10,709 & 10,686 & 10,658 & 10,683 & 10,699 & 10,684 \\
\hline R-squared & 0.935 & 0.909 & 0.903 & 0.899 & 0.926 & 0.931 \\
\hline
\end{tabular}

Standard errors in parentheses

${ }^{* * *} p<0.01,{ }^{* *} p<0.05,{ }^{*} p<0.1$ 
Additionally, the coefficient of $\mathrm{fta} 1$ and $\mathrm{fta} 2$ are significant. The positive coefficient value of ftal infers that if the trade partner is a member of AKFTA, exports of primary products will increase by $46 \%$, holding other factors constant. In this case, the effect of trade diversion is also positive, meaning that the exports volume for primary products to the non-member countries is increasing even though there is no schedule for tariff reduction with a non-member. The coefficient of $\mathrm{ftal}>\mathrm{fta}$, the coefficient value infers that the export of primary products will be higher if the trade partner is a member of AKFTA than nonmember countries. In other words, there is a case of import diversion effects.

In Column (3), coefficients of variable GDP are statistically significant at $1 \%$ except for dummy fta1. If GDP exporter increases by $1 \%$, total export will increase as much as 0.50 $\%$. Then, a $1 \%$ increase in GDP importer will increase total export by $0.68 \%$. In this case, GDP positively impacts export of natural-resource intensive products. Later on, in the case of trade openness, it has a significant statistical coefficient, and the sign is positive. So, this variable positively impacts the export of natural-resource intensive products. If there is a $1 \%$ increase in the variable, then the export of natural-resource intensive products will incline of about $0.16 \%$.

In the event of remoteness, the variable remoteness exporter is positive and significant. Thus, this variable has a positive impact on the export of natural-resource intensive products. If there is a $1 \%$ increase in the variable, then the export of natural-resource intensive products will increase by about $1.89 \%$. However, this result is not following the theory. The remoteness importer has a negative sign. As a proxy for transportation cost, if there is a $1 \%$ increase in these variables, then the export of natural-resource intensive products will decrease by about $0.02 \%$. The export volume of natural-resource intensive products will decline if the trade cost increases.

In the case of the real exchange rate, it also has a negative sign, in contrast with the theory, even though the coefficient is significant. Holding other factors constant, if the real exchange rate of the Indonesian Rupiah to the currency of the export partner country increases by $1 \%$, the export of natural-resource intensive products will decrease by $2.15 \%$.

The coefficients of fta 1 , however, change drastically insignificant. However, fta 2 is significant at $1 \%$ level. Dummy fta 1 has positive sign meaning that there is no evidence for trade creation effect between Indonesia and member countries for natural-resource intensive products. The coefficient sign of $\mathrm{fta} 2$ is negative, means that when the trade partner is a non-member of AKFTA, Indonesian export to this particular country will be less than those who are a member of AKFTA. The coefficient value infers that if the trade partner is a non-member of AKFTA, Indonesian export of natural-resource products will decline by $89 \%$, holding other factors constant. So, only the trade diversion effect occurs in this case.

In Column (4), coefficients of variable GDP are statistically significant except for trade openness variable that has significance level of 5\%. If GDP exporter increases by $1 \%$, export of unskilled-labor intensive products will increase as much as $0.52 \%$. Then, a $1 \%$ increase 
in GDP importer will increase total export by $0.441 \%$. In this case, GDP positively impacts export of unskilled-labor intensive products. In the case of remoteness, both remoteness exporter and importer have a negative sign. As a proxy for transportation cost, if there is a $1 \%$ increase in these variables, then the export of Indonesia will go down to about $7.97 \%$ and $0.02 \%$, respectively.

Later on, in the case of trade openness, the sign is statistically significant with the positive sign, in line with the theory. If there is $1 \%$ increase in this variable, consequently, the unskilled-labor intensive products export volume will increase by $0.06 \%$. In the case of the real exchange rate, it has no significant coefficient, meaning that this variable has nothing to do with the export of unskilled-labor intensive products. Besides, the coefficients of fta1 and $\mathrm{fta} 2$ are also significant at $1 \%$ level, and both are negative. Dummy fta1 has negative sign meaning that there is no evidence of trade creation between Indonesia and member countries regarding unskilled-labor intensive products export. The ftal coefficient value infers that if the trade partner is a member of AKFTA, Indonesian exports of unskilled-labor intensive products export will go down as much as $0.207 \%$. The coefficient sign of $\mathrm{fta} 2$ is also negative, means that when the trade partner is a non-member of AKFTA, Indonesian exports to this particular country will be less than those who are a member of AKFTA. If the trade partner is a non-member of AKFTA, Indonesian exports of unskilled-labor intensive products export will decrease by $1.04 \%$, holding other factors constant. As fta $1<0, \mathrm{fta} 2<0$ and $\mathrm{fta} 1>\mathrm{fta} 2$, this means that there are no longer trade creation effects and a total of import diversion on the export of unskilled-labor intensive products identified.

In Column (5), coefficients of all of the variables are significant, except for dummy $\mathrm{fta} 2$ that is significant at 5\% level. For the primary variables of GDP, if the GDP exporter increases by $1 \%$, exports of technology-intensive products will increase as much as 0.01 $\%$. After that, a $1 \%$ increase in GDP importer will increase total export by $0.43 \%$. In the case of remoteness, the variable remoteness exporter is positive and significant. Thus, this variable has a positive impact on the exports of technology-resource intensive products. If there is a $1 \%$ increase in the variable, then the export of technology-resource intensive products will increase by about $0.01 \%$. However, this result is not following the theory. The remoteness importer has a negative sign. If there is a $1 \%$ increase in these variables, then the total exports of Indonesia will decrease by about $2.5 \%$. The export volume of technologyresource intensive products will decline if the trade cost increases.

The trade openness had a positive impact on total export volume. If there is $1 \%$ increase in this variable, consequently, the total export volume will go down $0.24 \%$. Additionally, the real exchange rate also has a negative sign, in contrast with the theory, even though the coefficient is significant. If the real exchange rate of the Indonesian Rupiah to the currency of the export partner country increases by $1 \%$, exports to Indonesia will go down about $1.52 \%$.

Besides, the coefficients of fta 1 and fta 2 are also significant, and both are negative. Dummy fta 1 has negative sign meaning that there is no evidence of trade creation between Indonesia and member countries regarding technology-intensive products export. The ftal 
coefficient value infers that if the trade partner is a member of AKFTA, Indonesian export of technology-intensive products export will go down as much as $29 \%$. The coefficient sign of fta2 is also negative, means that when the trade partner is a non-member of AKFTA, Indonesian export to this particular country will be less than those who are a member of AKFTA. If the trade partner is a non-member of AKFTA, Indonesian export of technologyintensive products export will decrease by $11 \%$, holding other factors constant. As $\mathrm{fta} 1<0$, $\mathrm{fta} 2<0$ and $\mathrm{fta} 1<\mathrm{fta} 2$, this means that there are no longer trade creation effects and a total of trade diversion or trade contraction on the export of unskilled-labor intensive products identified.

In Column (6), coefficients of all of the variables are significant at the $1 \%$ level with expected signs, except for the real exchange rate that has a negative sign and fta 2 that is significant at the $5 \%$ level. For the primary variables of GDP, if the GDP exporter increases by $1 \%$, total exports will increase as much as $0.61 \%$. After that, a $1 \%$ increase in the GDP importer will increase exports of human-capital intensive products by $0.66 \%$. In this case, GDP positively impacts trade.

Variables remoteness exporter is significant at the $1 \%$ level, and the sign is positive, in contrast with the theory. As a proxy for transportation cost, Indonesian exports will decrease by about $0.02 \%$ when there is $1 \%$ increase in this variable. On the other hand, in line with the theory, the remoteness importer has a negative sign. If there is a $1 \%$ increase in these variables, then the exports of human-capital intensive products will increase about $3.89 \%$. The export volume of primary goods will decline if the trade cost increases.

Afterward, in the case of trade openness, it has a statistically significant coefficient. If there is a $1 \%$ increase in this variable, consequently, the total export volume will go up $0.23 \%$. The real exchange rate is also positive coefficient and statistically significant. It means that this variable has a positive impact on the export of human-capital intensive products. If there is $1 \%$ increase in this variable, the export volume of human-capital intensive products will go up by $2.5 \%$.

Later on, the coefficients of $\mathrm{fta} 1$ and $\mathrm{fta} 2$ are also significant at the 5\% and $1 \%$ level, respectively. Dummy fta1 has a positive sign meaning that there is trade creation between Indonesia and member countries. If the partner country is a member of AKFTA, Indonesian exports of human-capital intensive products will go up by $21 \%$, holding other factors constant. The coefficient sign of $\mathrm{fta} 2$ is negative, which means that when the trade partner is a non-member of AKFTA, Indonesian exports to this particular country will be smaller than to those who are members of AKFTA. The coefficient value infers that if the trade partner is a non-member of AKFTA, Indonesian exports of human-capital intensive products will decrease by $24 \%$, holding other factors constant. As $\mathrm{fta} 1>0, \mathrm{fta} 2<0$ and $\mathrm{fta} 1>\mathrm{fta} 2$, both effects in human-capital-intensive products are identified.

\section{Conclusion}

This study highlights the inclusion of FTA dummy variables in a gravity equation to estimate the impact of AKFTA implementation, focusing on trade creation and trade 
diversion effects. All results show that for the variables of the gravity model, especially GDP exporter, GDP importer, and trade openness generate expected signs. Following the theory, these two variables are proven to affect Indonesian bilateral trade from imports and exports side positively. However, the variables remoteness exporter and remoteness importer vary depending on the commodity. For the real exchange rate, the sign is negative, in contrast with the theory.

In case of total export, there is weak evidence of trade creation but strong trade diversion effects from nonmembers. The results on total exports of manufacturing products, there is no evidence that the establishment of AKFTA increases the Indonesian exports from member countries. However, there is evidence of decreasing the total exports of manufacturing products from non-member countries. In the case of disaggregated data, trade creation effect has identified for primary products not only for the members but non-members as well. The results confirmed that reducing tariff barriers in AKFTA promotes total trade volume not only among member countries but also between member and non-member countries. In the case of naturalresources intensive products, only the trade diversion effect had detected. Unskilled-labor intensive products and technology-intensive products have negative impacts of trade creation, and the diversion effects had fully identified, while trade diversion outweighs trade creation effects concerning human-capital intensive products.

There are some policy implications. Firstly, Indonesian government should adequately investigate the impact of FTA on Indonesian trade since the effects might be beneficial or harmful. Secondly, since pure trade creation has detected for primary products, these products development will be beneficial in the future. Finally, Indonesian governments should strengthen other categories of manufacturing goods that have poor export performance. For future research, it is necessary to take into consideration more disaggregated data for specific commodities in Indonesia. In the meantime, the impact of trade facilitation, such as products standards, simplification of customs clearance procedures, may become interesting research.

\section{Acknowledgment}

This paper is a revised paper of my master thesis submitted to Ritsumeikan University and Universitas Indonesia. I would like to show my gratitude to my supervisors, Prof. Masayuki Okawa and Prof. Kei Sakata, who provided insight and expertise that greatly assisted the research.

\section{References}

Adam, C., \& Cobham, D. (2007). Modelling multilateral trade resistance in a gravity model with exchange rate regimes. Centre for Dynamic Macroeconomic Analysis Conference Papers. Vol. 44: 1-49.

Agnosteva, D. E., Anderson, J. E., \& Yotov, Y. V. (2014). Intra-national Trade Costs: Measurement and Aggregation. NBER Working Paper No. 19872. doi: https://doi. org/10.3386/w19872. 
Baier, S. L., \& Bergstrand, J. H. (2007). Do Free Trade Agreements Actually Increase Members' International Trade? Journal of International Economics. Vol. 71 (1): 72-95. doi: https://doi.org/10.1016/j.jinteco.2006.02.005.

Carrère, C. (2006). Revisiting The Effects of Regional Trade Agreements on Trade Flows with Proper Specification of The Gravity Model. European Economic Review. Vol. 50(2): 223-247. doi: https://doi.org/10.1016/j.euroecorev.2004.06.001.

Cheng, I., \& Wall, H. J. (2005). Controlling for Heterogeneity in Gravity Models of Trade and Integration. Federal Reserve Bank of St. Louis Review. Vol. 87(1): 49-63.

Devadason, E. S. (2010) ASEAN-China Trade Flows: Moving Forward with ACFTA. Journal of Contemporary China. Vol. 19 (66): 653-674. doi: https://doi.org/ 10.1080/10670564.2010.485403

Egger, P. H., \& Nigai, S. (2015). Structural Gravity with Dummies Only: Constrained ANOVA-type Estimation of Gravity Models. Journal of International Economics. Vol. 97(1): 86-99. https://doi.org/10.1016/j.jinteco.2015.05.004

Elliott, R. J., \& lkemoto, K. (2004). AFTA and the Asian Crisis: Help or Hindrance to ASEAN Intra-Regional Trade? Asian Economic Journal. Vol. 18 (1): 1-23. doi: https:// doi.org/10.1111/j.1467-8381.2004.00179.x.

French, S. (2011). The Composition of Exports and Gravity. Working Paper. University of New South Wales.

Ha, Y. S., Chung, K. J., \& Seo, J. S. (2016). An Analysis of Korea-ASEAN Trade and its Implications for the Shipping Industry in Korea. Asian Journal of Shipping and Logistics. Vol. 32(2): 63-71. doi: https://doi.org/10.1016/j.ajsl.2016.06.002

Heo, Y., \& Kien, T. N. (2013). Korea-ASEAN Trade Flows and the Role of AFTA: SectorSpecific Evidence of Trade Diversion. Journal of International Logistics and Trade. Vol. 10(2): 21-45.

Jayasinghe, S., \& Sarker, R. (2008). Effects of Regional Trade Agreements on Trade in Agrifood Products: Evidence from Gravity Modeling Using Disaggregated Data. Review of Agricultural Economics. Vol. 30(1): 61-81. doi: https://doi.org/10.1111/ j.1467-9353.2007.00392.x

Jugurnath, B., Stewart, M., \& Brooks, R. (2007). Asia/Pacific Regional Trade Agreements: An Empirical Study. Journal of Asian Economics. Vol. 18: 974-987. doi: https://doi. org/10.1016/j.asieco.2007.09.003.

Kahouli, B, \& Maktouf, S. (2015). Trade Creation and Diversion effects in The Mediterranean Area: Econometric Analysis by Gravity Model. The Journal of International Trade \& Economic Development. Vol. 24(1): 76-104. doi: https://doi.org/10.1080/09638199.20 13.873479 .

Kepaptsoglou, K., Karlaftis, M. G., \& Tsamboulas, D. (2010). The Gravity Model Specification for Modeling International Trade Flows and Free Trade Agreement Effects: A 10-Year Review of Empirical Studies. The Open Economics Journal. Vol. 3(1): 1-13. doi: https://doi.org/10.2174/1874919401003010001 
Kien, N. T. (2009). Gravity Model by Panel Data Approach; An Empirical Application with Implications for the ASEAN Free Trade Area. ASEAN Economic Bulletin. Vol. 26(3): 266-277. doi: https://doi.org/10.1355/ae26-3c.

Macphee, C. R., \& Sattayanuwat, W. (2014). Consequence of Regional Trade Agreements to Developing Countries. Journal of Economic Integration. Vol. 29(1): 64-94. doi: https:// doi.org/10.11130/jei.2014.29.1.64.

Magee, C. S. P. (2008). New Measures of Trade Creation and Trade Diversion. Journal of International Economics. Vol. 75: 349-362. doi: https://doi.org/10.1016/j. jinteco.2008. 03.006

Matyas, L. (1997). Proper Econometric Specification of The Gravity Model. The World Economy. Vol. 20: 262-302. doi: https://doi.org/10.1111/1467-9701-00074.

Narayan, S \& Nguyen T. T. (2016). Does The Trade Gravity Model Depend on Trading Partners? Evidence from Vietnam and 54 Trading Partners. International Review of Economics and Finance. Vol. 41: 220-237. doi: https://doi.org/10.1016/j.iref.2015.08. 010.

Okabe, M., \& Urata, S. (2014). The Impact of AFTA on Intra-AFTA Trade. Journal of Asian Economics. Vol. 35: 12-31. doi: https://doi.org/10.1016/j.asieco.2014.09.004

Olivero, M. P., \& Yotov Y. V. (2012). Dynamic Gravity: Endogenous Country Size and Asset Accumulation. Canadian Journal of Economics/Revue canadienne d'économique. Vol. 45(1): 64-92. doi: 10.1111/j.1540-5982.2011.01687.x

Park, D., Park, I., \& Estrada, G. E. B. (2008). Is the ASEAN-Korea Free Trade Area (AKFTA) an Optimal Free Trade Area? ADB Working Paper Series No. 21 on Regional Economic Integration.

Piermartini, R., \& Yotov, Y. V. (2016). Estimating Trade Policy Effects with Structural Gravity. WTO Working Paper. Vol. (10): 1-63. doi: https://doi.org/10.1007/s10273011-1262-2

Silva, J. M. C. S., \& Tenreyro, S. (2006). The Log of Gravity. Review of Economics and Statistics. Vol. 88(4): 641-658. doi: https://doi.org/10.1162/rest.88.4.641

Soloaga, I., \& Winters, L. A. (2001). Regionalism in the Nineties: What Effect on Trade? North American Journal of Economics and Finance. Vol. 12(1): 1-29. doi: http://doi.org/ 10.1016/S1062-9408(01)00042-0

Trotignon, J. (2016). Does Regional Integration Promote the Multilateralization of Trade Flows ? A Gravity Model Using Panel Data. Journal of Economic Integration. Vol. 25(2): 223-251.

Urata, S., \& Okabe, M. (2014). Trade Creation and Diversion Effects of Regional Trade Agreements : A Product-level Analysis. The World Economy. Vol. 37 (2): 267-289. doi: https://doi.org/10.1111/twec.12099.

Yang, S., \& Martinez-zarzoso, I. (2014). China Economic Review A Panel Data Analysis of Trade Creation and Trade Diversion Effects: The Case of ASEAN-China Free Trade Area. China Economic Review. Vol. 29: 138-151. doi: https://doi.org/j. chieco.2014.04. 002 . 
Etikonomi

Volume 17 (2), 2018: 161 - 184

Zidi, A. \& Dhifallah, S. M (2013). Trade Creation and Trade Diversion between Tunisia and EU: Analysis by Gravity Model. International Journal of Economics and Finance. Vol. 5(5): 131-147. doi: https://doi.org/10.5539/ijef.v5n5p131. 


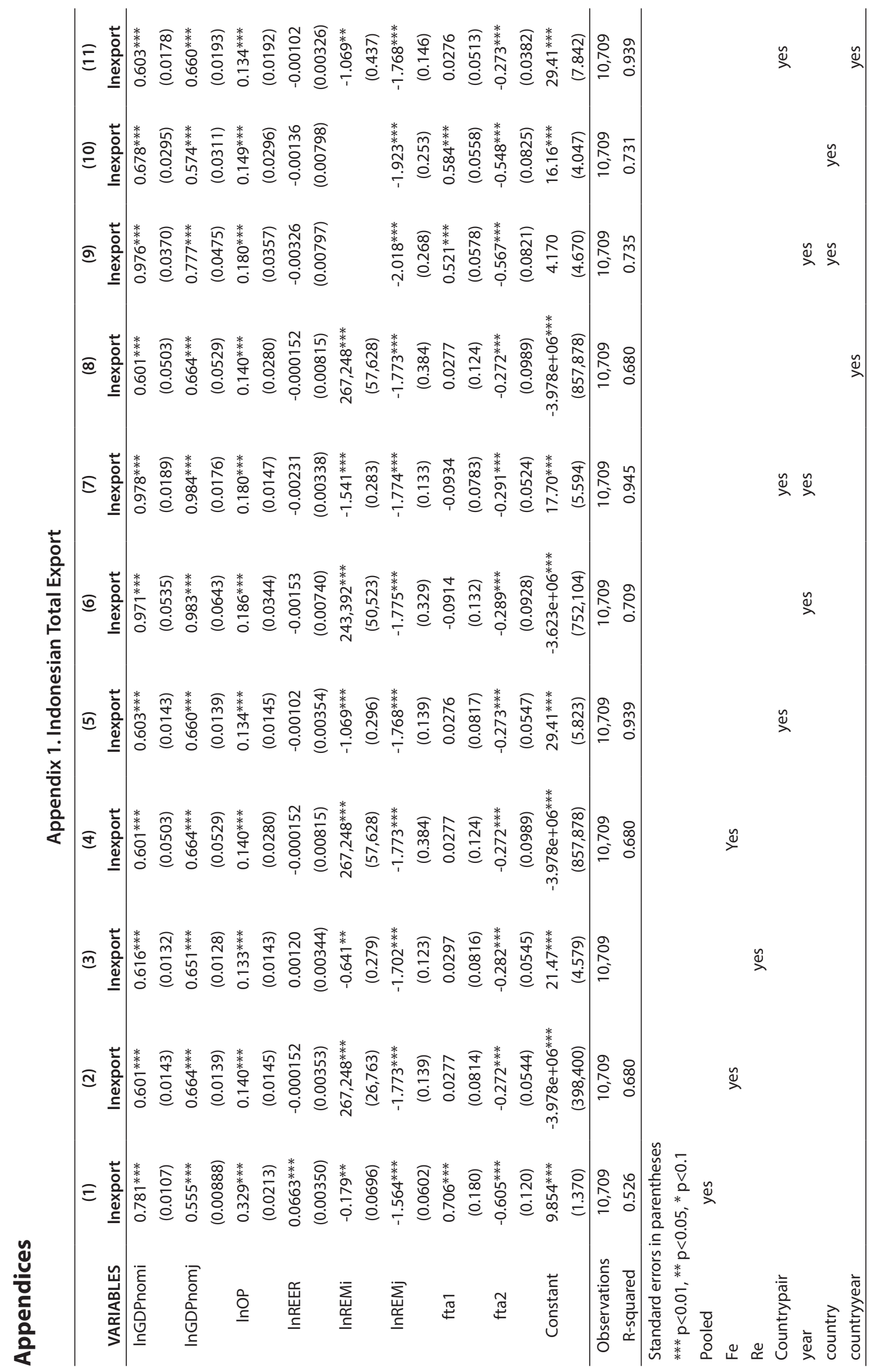




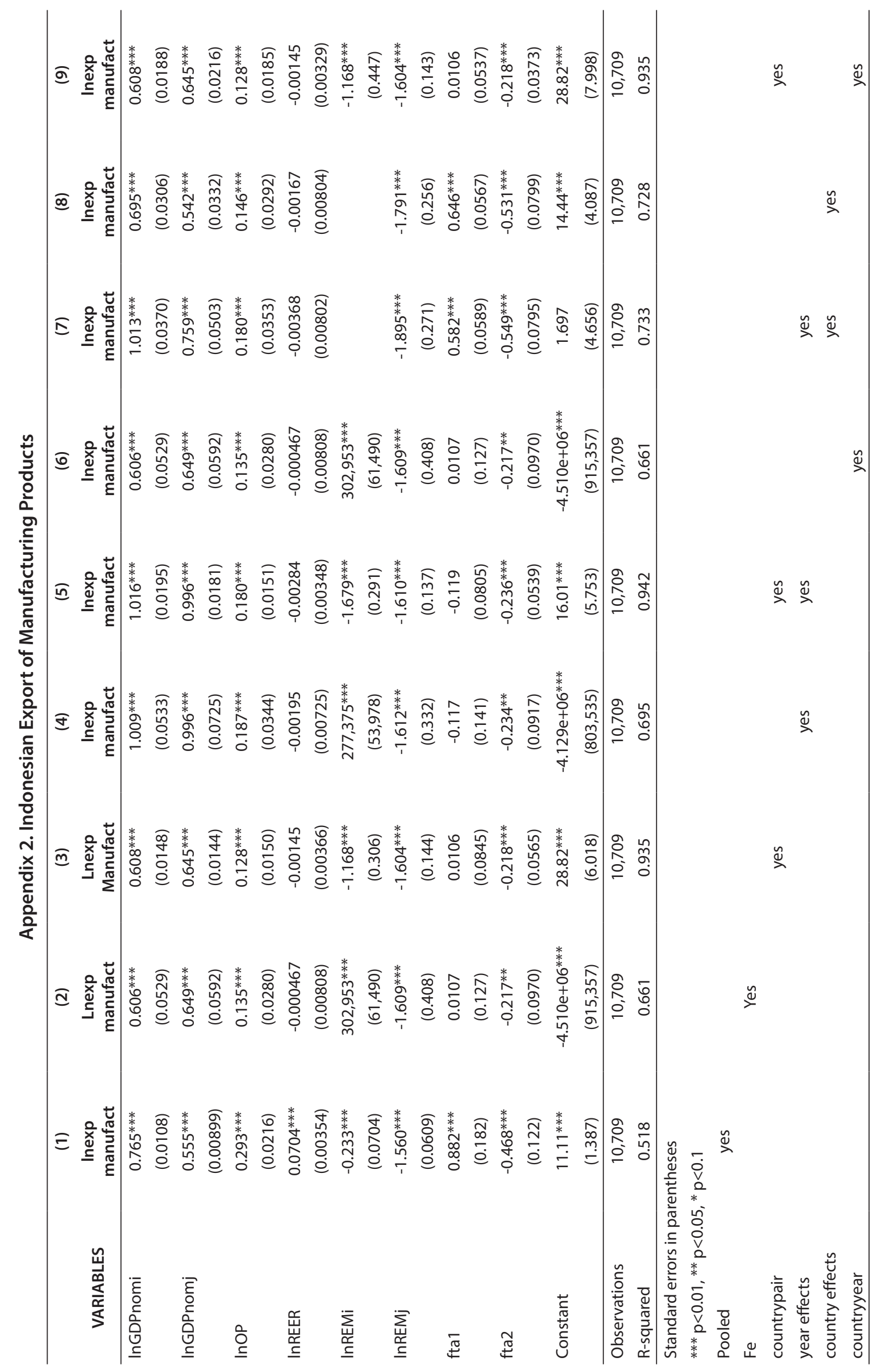




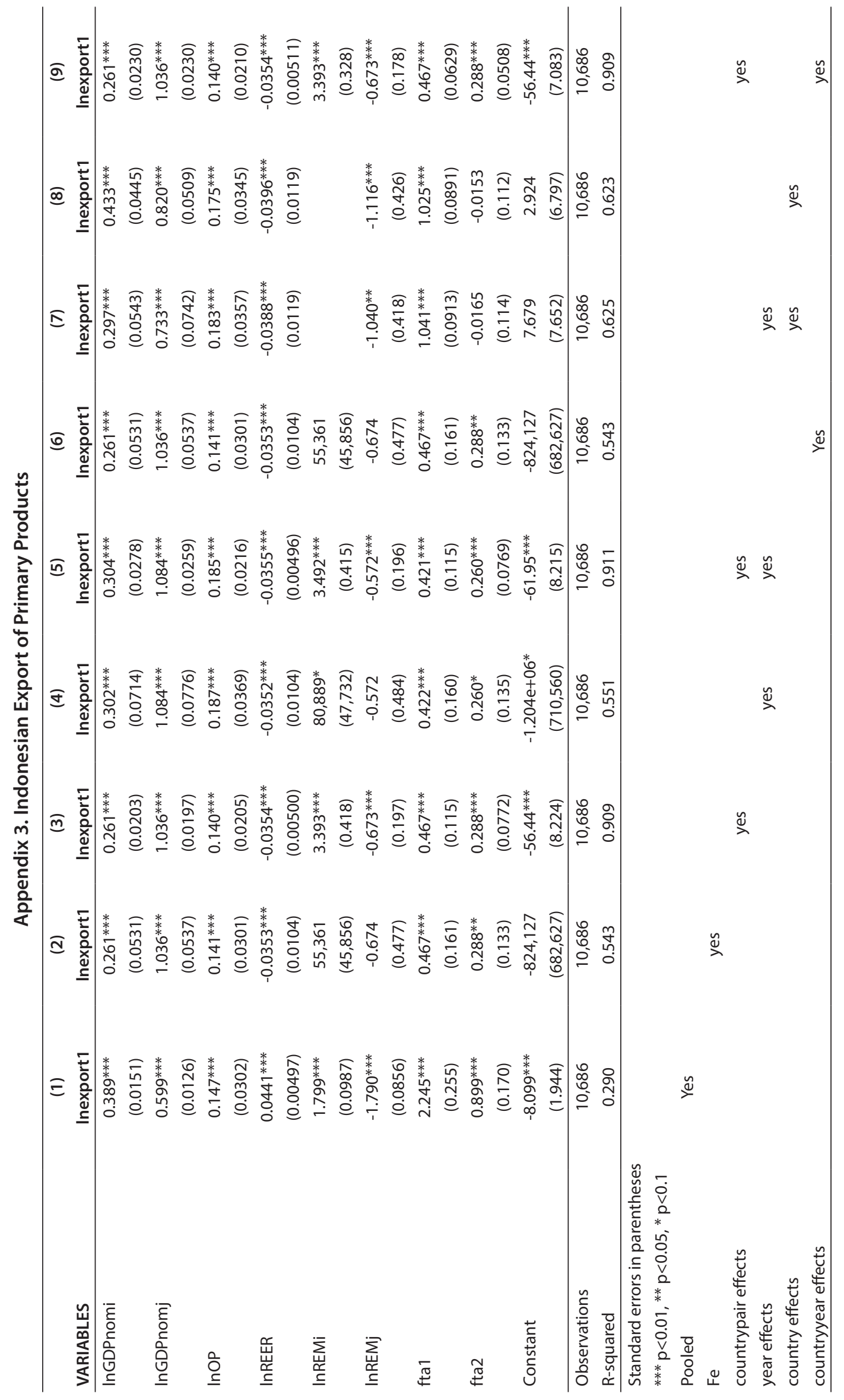




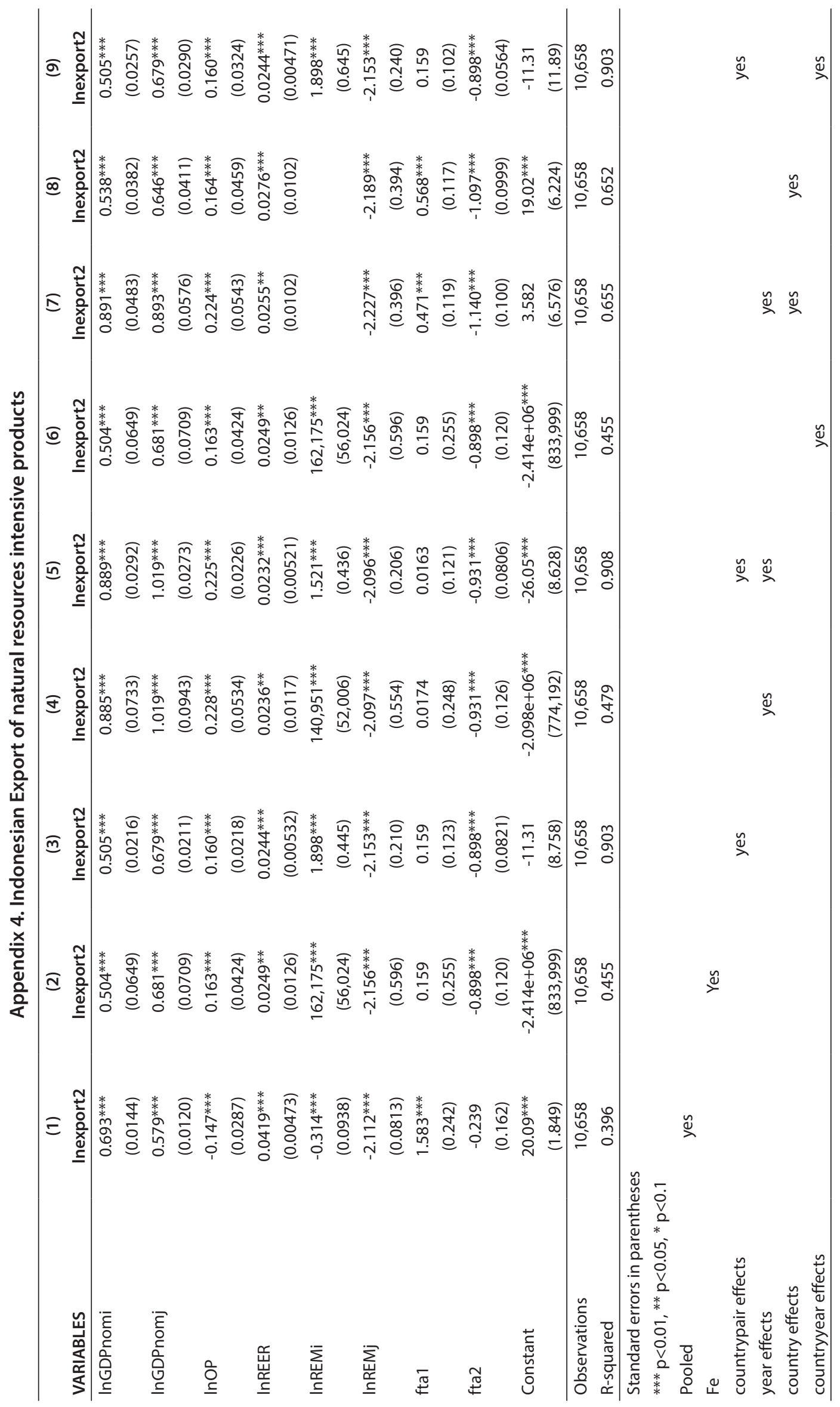




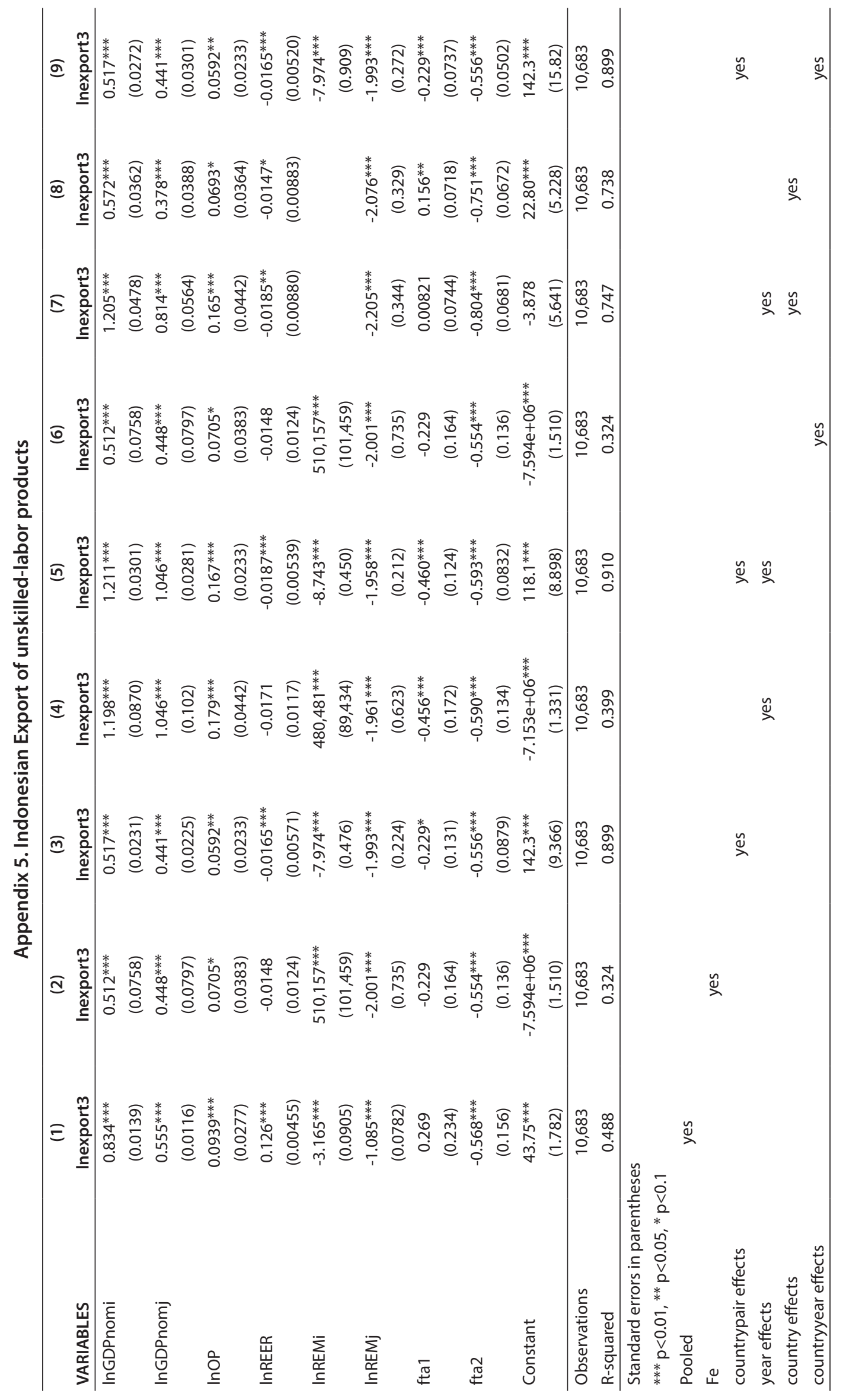




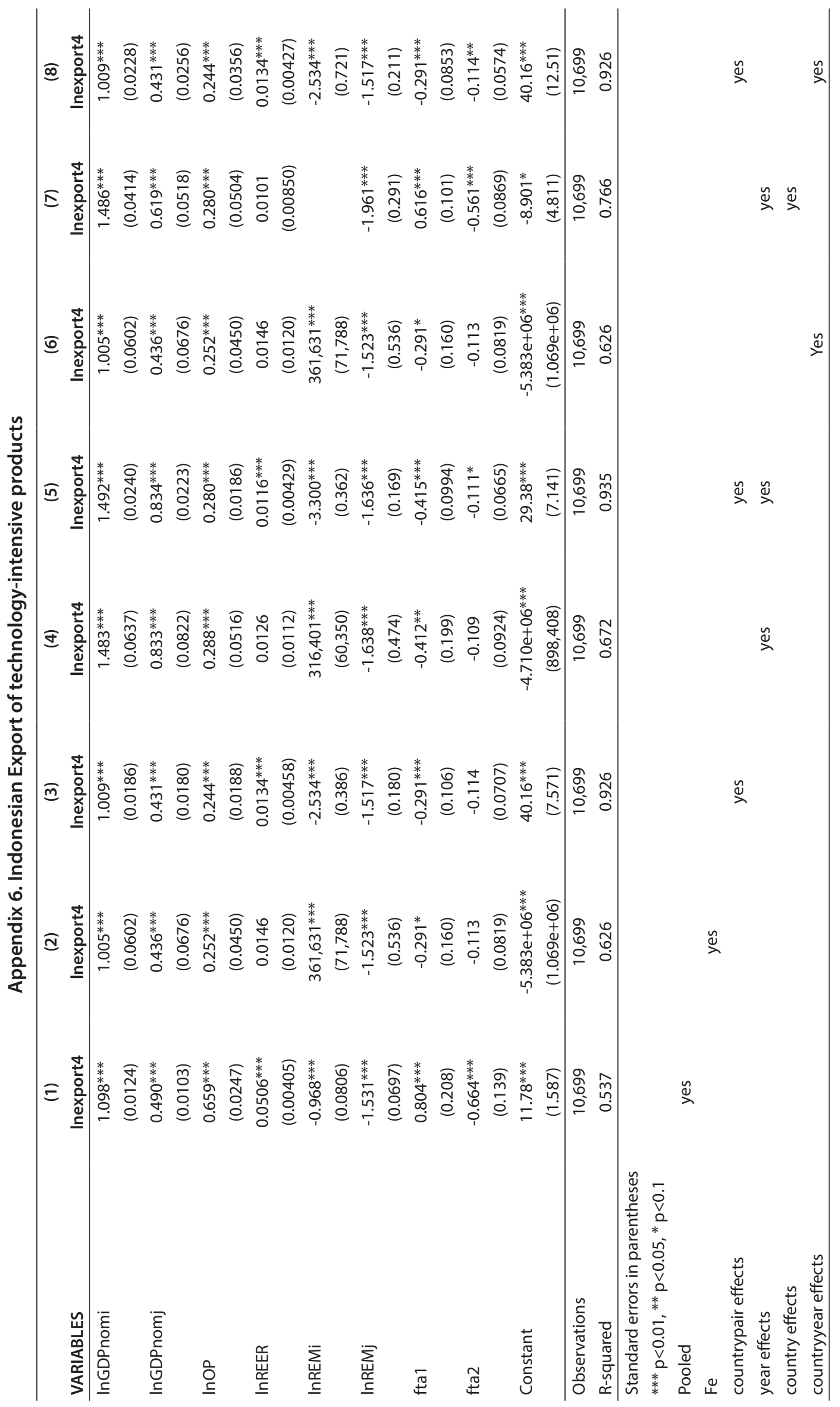




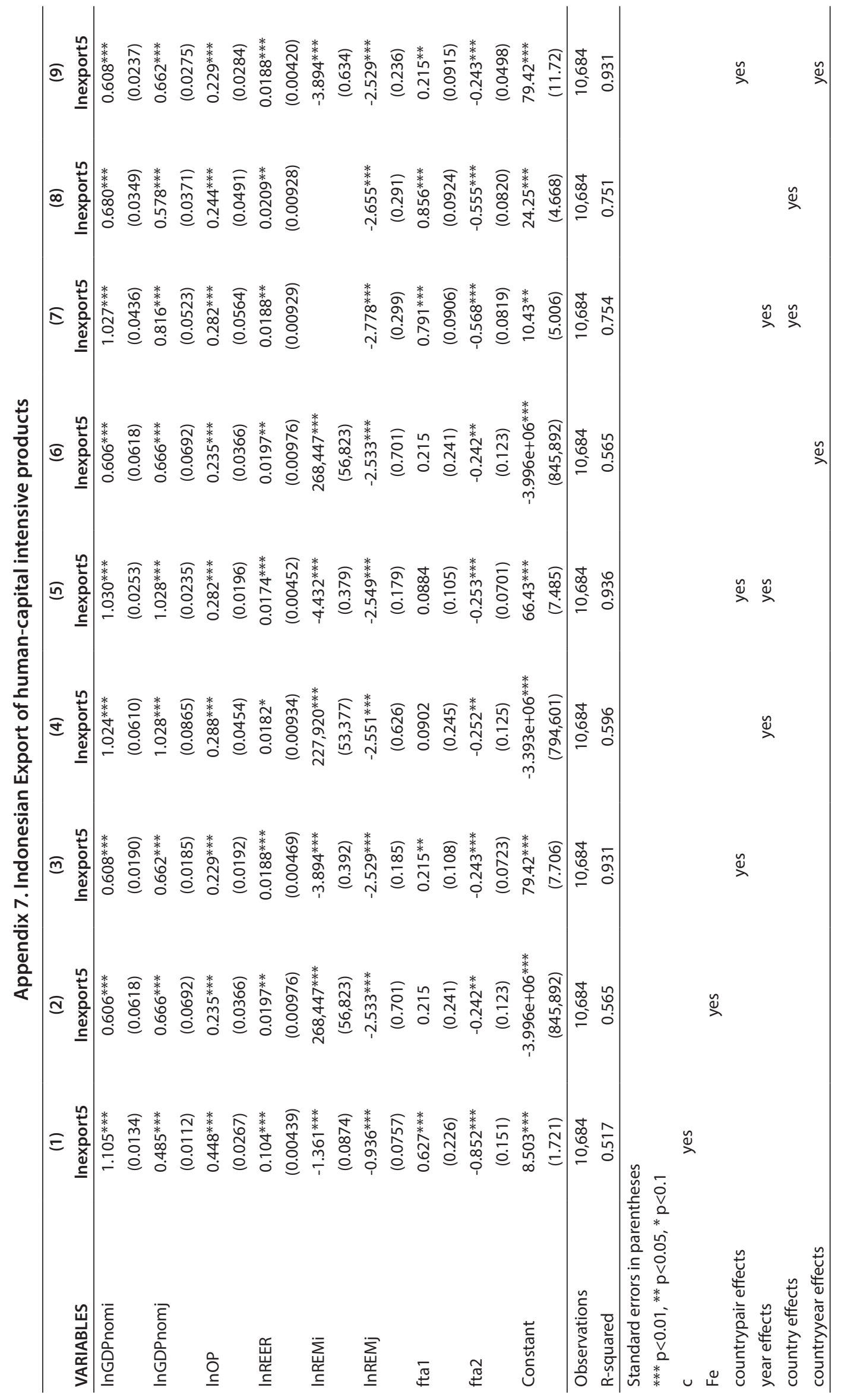

